\title{
Larkinella insperata gen. nov., sp. nov., a bacterium of the phylum 'Bacteroidetes' isolated from water of a steam generator
}

Correspondence

Marc Vancanneyt

Marc.Vancanneyt@UGent.be

\author{
Marc Vancanneyt, ${ }^{1}$ Olga I. Nedashkovskaya, ${ }^{2}$ Cindy Snauwaert, ${ }^{1}$ \\ Stefanie Mortier, ${ }^{1}$ Katrien Vandemeulebroecke, ${ }^{1}$ Bart Hoste, ${ }^{1}$ \\ Peter Dawyndt, ${ }^{3}$ Galina M. Frolova, ${ }^{2}$ Danielle Janssens ${ }^{1}$ \\ and Jean Swings ${ }^{1,3}$ \\ ${ }^{1,3}$ BCCM/LMG Bacteria Collection ${ }^{1}$ and Laboratory of Microbiology ${ }^{3}$, Ghent University, \\ Ledeganckstraat 35, B-9000 Ghent, Belgium \\ ${ }^{2}$ Pacific Institute of Bioorganic Chemistry of the Far-Eastern Branch of the Russian Academy \\ of Sciences, Pr. 100 Let Vladivostoku 159, 690022, Vladivostok, Russia
}

The Flexibacter group within the phylum 'Bacteroidetes' (previously Cytophaga-Flavobacterium-Bacteroides or CFB) is a phylogenetically diverse group of micro-organisms. One of the lineages in this group comprises the genera Spirosoma, Runella and Flectobacillus, currently classified in the family Spirosomaceae (Larkin \& Borrall, 1984). The genera Spirosoma and Flectobacillus each comprise one species, Spirosoma linguale and Flectobacillus major, respectively. The genus Runella includes two species, Runella slithyformis (type species) and Runella zeae (Chelius et al., 2002). Other more recently discovered taxa related to species of the latter family are the distantly related genera Dyadobacter and Arcicella (Chelius \& Triplett, 2000; Nikitin et al., 2004; Reddy \& Garcia-Pichel, 2005). A characteristic morphological feature of the majority of members of the above-mentioned genera is the formation of ring-like or horseshoe-shaped cells, except for cells of $R$. zeae and Dyadobacter species, which are straight to curved rods. In the present report, the genotypic and phenotypic properties of strain LMG $22510^{\mathrm{T}}$, which was isolated from water of a steam generator, are described; data show that the organism

Published online ahead of print on 16 September 2005 as DOI 10.1099/ijs.0.63948-0.

The GenBank/EMBL/DDBJ accession numbers for the 16S rRNA gene sequences of Larkinella insperata LMG $22510^{\top}$ and Spirosoma linguale LMG $10896^{\top}$ are AM000022 and AM000023, respectively. should be classified as a novel species in a new genus in the Flexibacter group of the phylum 'Bacteroidetes'.

Strain LMG $22510^{\mathrm{T}}$ was isolated and purified from cooled water produced by a steam generator in a pharmaceutical company in Belgium in 2004. The Gram-negative cells have ring-like and horseshoe-shaped morphology and gliding motility. Colonies produce non-diffusible pale-pink pigments on tryptic soy agar (BBL) at $28{ }^{\circ} \mathrm{C}$ under aerobic conditions. The latter cultivation conditions were used for maintenance of the cultures and further experiments, unless indicated otherwise.

The phylogenetic position of strain LMG $22510^{\mathrm{T}}$ was determined by complete $16 \mathrm{~S}$ rRNA gene sequence analysis. Genomic DNA was prepared according to the protocol of Niemann et al. (1997). 16S rRNA gene amplification, purification and sequencing were performed as described by Vancanneyt et al. (2004) except that 16S rRNA gene amplicons were purified using a NucleoFast 96 PCR Cleanup kit (Macherey-Nagel). Sequencing reactions were performed using a BigDye Terminator Cycle Sequencing kit (Applied Biosystems) and purified using a Montage $\mathrm{SEQ}_{96}$ Sequencing Reaction Clean-up kit (Millipore). Electrophoresis of sequence reaction products was performed using an ABI Prism 3100 Genetic Analyzer (Applied Biosystems). Sequence assembly was performed using the program AutoAssembler (Applied Biosystems). The 16S rRNA gene 
sequences (continuous stretch of $1466 \mathrm{bp}$ ) and sequences retrieved from GenBank/EMBL of related reference strains were aligned and a phylogenetic tree was constructed by the neighbour-joining method using the BioNumerics software package (version 3.5; Applied Maths). Unknown bases were discarded for the analyses. Bootstrapping analysis was undertaken to test the statistical reliability of the topology of the neighbour-joining tree using 500 bootstrap resamplings of the data (Fig. 1). Comparison of the sequences revealed highest sequence similarity $(88 \cdot 1 \%)$ between strain LMG $22510^{\mathrm{T}}$ and S. linguale ATCC 23276.

Because no $16 \mathrm{~S}$ rRNA gene sequence was publicly available for the type strain of $S$. linguale, the nearly complete gene sequence (continuous stretch of $1460 \mathrm{bp}$ ) was determined for S. linguale LMG $10896^{\mathrm{T}}$ using the same methodology and approach as described above. A similarity of $97 \cdot 8 \%$ was calculated between the sequences of S. linguale strains LMG $10896^{\mathrm{T}}$ and ATCC 23276. S. linguale LMG $10896^{\mathrm{T}}$ and strain LMG $22510^{\mathrm{T}}$ shared a similarity of $88 \cdot 8 \%$. Similarity values with the type strains of the type species of the genera Arcicella, Dyadobacter, Flectobacillus and Runella, more distantly related taxa, were lower $(83 \cdot 6-86 \cdot 3 \%)$.

For determination of DNA base content, DNA was extracted following the protocol of Pitcher et al. (1989) as modified by Leisner et al. (2002). DNA was enzymically degraded into nucleosides as described by Mesbah et al. (1989). The nucleoside mixture obtained was separated by HPLC using a Waters Symmetry Shield C8 column maintained at $37^{\circ} \mathrm{C}$. The solvent was $0.02 \mathrm{M} \mathrm{NH}_{4} \mathrm{H}_{2} \mathrm{PO}_{4}(\mathrm{pH} 4 \cdot 0)$ with $1.5 \%$ acetonitrile. Non-methylated phage lambda DNA (Sigma) was used as the calibration reference. The DNA $\mathrm{G}+\mathrm{C}$ content of strain LMG $22510^{\mathrm{T}}$ was 53 mol\%.

Determination of the fatty acid methyl ester composition of strain LMG $22510^{\mathrm{T}}$ and its nearest neighbour S. linguale LMG $10896^{\mathrm{T}}$ was performed using the standard protocol of the Sherlock Microbial Identification System (version 5.0; MIDI). Dominant fatty acids for both strains studied are summarized in Table 1 and included $15: 0$ iso, $16: 1 \omega 5 c$, $17: 0$ iso $3-\mathrm{OH}$ and summed feature 3 (comprising 15:0 iso 2-OH, 16: $1 \omega 7 \mathrm{c}$ and/or $16: 1 \omega 7 t$; cf. Table 1). Major quantitative differences between LMG $22510^{\mathrm{T}}$ and S. linguale LMG $10896^{\mathrm{T}}$ were found in the amounts of the above-mentioned fatty acids. Apart from the latter differences, strain LMG $22510^{\mathrm{T}}$ can be distinguished from S. linguale by the presence of small amounts of 14:0 and 16:0 iso $3-\mathrm{OH}$ and by the absence of $13: 0$ iso.

Isoprenoid quinones were extracted from lyophilized cells and analysed as described by Akagawa-Matsushita et al. (1992). Menaquinones were detected by monitoring at $270 \mathrm{~nm}$ and were identified by comparison with known quinones from the reference strain, Cyclobacterium marinum LMG $13164^{\mathrm{T}}$. The main isoprenoid quinone was MK-7.

Analysis of polar lipids was carried out as described previously (Ivanova et al., 2000). Phospholipids of LMG $22510^{\mathrm{T}}$ were phosphatidylethanolamine and phosphatidylserine. Also, one glycolipid and four unidentified lipids were detected.

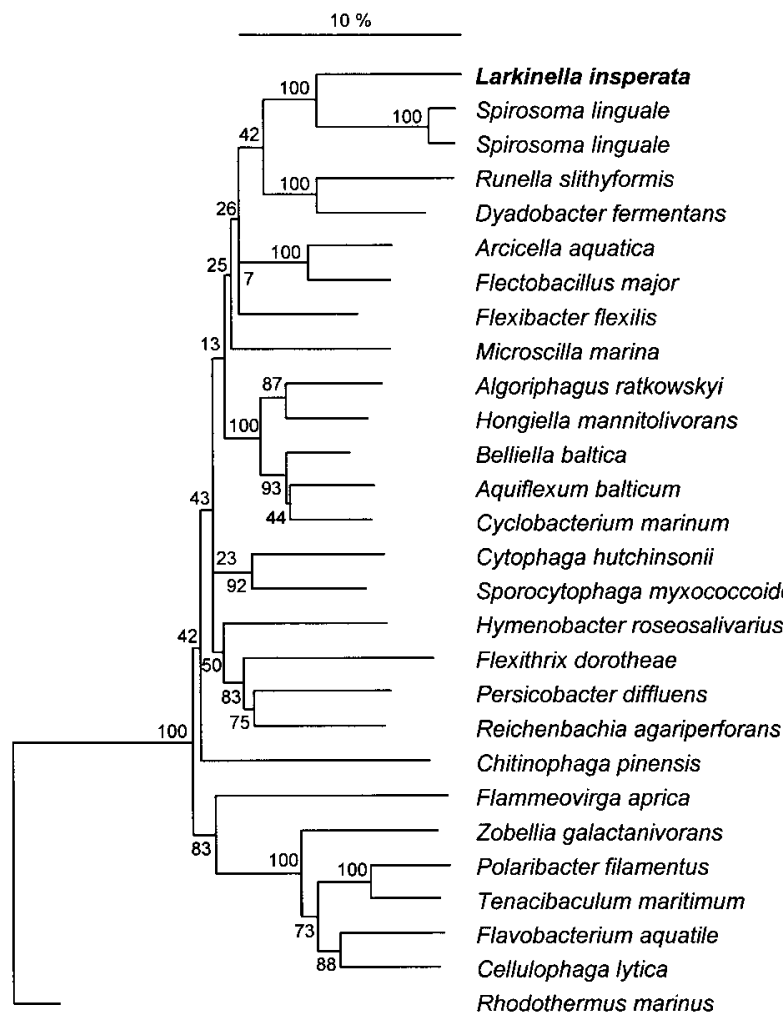

\begin{tabular}{|c|c|}
\hline LMG $22510^{\top}$ & \\
\hline LMG $10896^{\top}$ & AM000023 \\
\hline TCC 23276 & M62789 \\
\hline TCC $29530^{\top}$ & M62786 \\
\hline $\operatorname{IS} 114^{\top}$ & AF13702S \\
\hline NO-502 ${ }^{\top}$ & AJ535729 \\
\hline ATCC $29496^{\top}$ & M62787 \\
\hline ATCC $23079^{\top}$ & M62794 \\
\hline ATCC $23134^{\top}$ & M58793 \\
\hline $\mathrm{C} 025^{\top}$ & U85891 \\
\hline DSM 15301T & AY264838 \\
\hline$B A 134^{\top}$ & AJ564643 \\
\hline $\mathrm{BA} 160^{\top}$ & A.J744861 \\
\hline LMG $13164^{\top}$ & AJ575266 \\
\hline ATCC $33406^{\top}$ & M58768 \\
\hline DSM 11118 & AJ310654 \\
\hline AA-718 & Y18833 \\
\hline ATCC $23163^{\top}$ & AF039296 \\
\hline ATCC 23140 & M58765 \\
\hline KMM $3525^{\top}$ & AB058919 \\
\hline ACM $2034^{\top}$ & AF078775 \\
\hline ATCC $23126^{\top}$ & D12655 \\
\hline Dsij & AF208293 \\
\hline ATCC $700397^{\top}$ & U73726 \\
\hline ATCC $43398^{\top}$ & M64629 \\
\hline ATCC $11947^{\top}$ & M62797 \\
\hline ATCC $23178^{\top}$ & M62796 \\
\hline DSM $4252^{\top}$ & AF2174 \\
\hline
\end{tabular}

Fig. 1. Phylogenetic tree based on $16 \mathrm{~S}$ rRNA gene sequences of Larkinella insperata LMG $22510^{\top}$ and Spirosoma linguale LMG $10896^{\top}$ and representative members of related genera within the Flexibacter group. Rhodothermus marinus was used as outgroup. Numbers at nodes indicate bootstrap values (\%). 
Table 1. Fatty acid content (mean percentages of total) of Larkinella insperata LMG $22510^{\top}$ and S. linguale LMG $10896^{\top}$

Strains: 1, L. insperata LMG $22510^{\mathrm{T}} ; 2$, S. linguale LMG $10896^{\mathrm{T}}$. Those fatty acids for which the amount for both taxa is less than $1 \%$ are not given; -, not detected; tr, less than $1 \%$.

\begin{tabular}{|lcc|}
\hline Fatty acid & $\mathbf{1}$ & $\mathbf{2}$ \\
\hline $13: 0$ iso & - & $3 \cdot 8$ \\
$14: 0$ & $1 \cdot 0$ & - \\
$15: 0$ iso & $13 \cdot 9$ & $7 \cdot 6$ \\
$15: 0$ anteiso & $1 \cdot 4$ & $\operatorname{tr}$ \\
$15: 0$ iso 3-OH & $2 \cdot 1$ & $4 \cdot 9$ \\
$16: 0$ & $3 \cdot 9$ & $7 \cdot 2$ \\
$16: 1 \omega 5 c$ & $48 \cdot 7$ & $17 \cdot 5$ \\
$16: 0$ 3-OH & $3 \cdot 6$ & $4 \cdot 7$ \\
$16: 0$ iso 3-OH & $1 \cdot 8$ & - \\
$17: 0$ iso 3-OH & $14 \cdot 3$ & $6 \cdot 5$ \\
SF3 & $8 \cdot 3$ & $47 \cdot 9$ \\
\hline
\end{tabular}

${ }^{\star}$ SF3, Summed feature 3 (summed features consist of one or more fatty acids that cannot be separated by the Microbial Identification System): $15: 0$ iso $2-\mathrm{OH}, 16: 1 \omega 7 c$ and/or $16: 1 \omega 7$.

Phenotypic analysis was performed using previously described methods (Nedashkovskaya et al., 2003, 2004). The physiological, biochemical and morphological characteristics of strain LMG $22510^{\mathrm{T}}$ are given in the species description and in Tables 2 and 3. Strain LMG $22510^{\mathrm{T}}$ and its nearest neighbour, S. linguale, have many similar properties, but also a significant number of distinct features, e.g. differences in hydrolysis of gelatin, starch, Tweens 20 and 80 , utilization and acid production from particular carbohydrates and susceptibility to antibiotics (Table 2). Phenotypic features, summarized in Table 3, demonstrate that the novel taxon also differs from other more distantly related genera.

Phylogenetic, genomic and phenotypic data clearly indicate that LMG $22510^{\mathrm{T}}$ represents a novel genus and species within the Flexibacter group, for which the name Larkinella insperata gen. nov., sp. nov. is proposed.

\section{Description of Larkinella gen. nov.}

Larkinella (Lar.ki.nel'la. N.L. fem. n. Larkinella named in honour of the American microbiologist John M. Larkin, who described the family Spirosomaceae in co-authorship with Renée Borrall).

Ring-like and horseshoe-shaped cells, motile by gliding. Gram-negative. Do not form endospores. Strictly aerobic. Produce non-diffusible pale-pink pigments. Chemoorganotroph. Cytochrome oxidase-, catalase- and alkaline phosphatase-positive. Dominant cellular fatty acids are $15: 0$ iso, $16: 1 \omega 5 c, 17: 0$ iso $3-\mathrm{OH}$ and summed feature 3 (comprising 15:0 iso $2-\mathrm{OH}, 16: 1 \omega 7 c$ and/or $16: 1 \omega 7 t$ ).
Table 2. Phenotypic properties of $L$. insperata LMG $22510^{\top}$ and its nearest phylogenetic neighbour $S$. linguale LMG $10896^{\top}$

Strains: 1, L. insperata LMG $22510^{\mathrm{T}}$; 2, S. linguale LMG $10896^{\mathrm{T}}$. Both strains produce ring-like and horseshoe-shaped cells. Both strains are positive for respiratory type of metabolism, motility by gliding, oxidase, catalase, $\beta$-galactosidase and alkaline phosphatase activities, hydrolysis of Tween 40, utilization of mannose and sucrose, susceptibility to ampicillin, carbenicillin and doxycycline and resistance to benzylpenicillin, chloramphenicol, gentamicin, neomycin and polymyxin B. Both strains are negative for nitrate reduction, flexirubin and $\mathrm{H}_{2} \mathrm{~S}$ production, $\mathrm{NaCl}$ requirement for growth, indole and acetoin (Voges-Proskauer reaction) production, hydrolysis of agar, casein, DNA, urea, cellulose (CM-cellulose and filter paper) and chitin, acid production from adonitol, L-arabinose, dulcitol, L-fucose, $\mathrm{N}$-acetylglucosamine, D-glucose, glycerol, inositol, D-lactose, Dmaltose, mannitol, D-melibiose, L-raffinose, L-rhamnose, sorbitol, L-sorbose, D-xylose and L-xylose and utilization of citrate, inositol, malonate, mannitol and sorbitol. W, Weakly positive.

\begin{tabular}{|c|c|c|}
\hline Characteristic & 1 & 2 \\
\hline \multicolumn{3}{|l|}{ Cell size $(\mu \mathrm{m})$} \\
\hline Outer diameter & $1 \cdot 5-3 \cdot 0$ & $1 \cdot 5-6 \cdot 0$ \\
\hline Width & $0 \cdot 5-0 \cdot 9$ & $0 \cdot 5-1 \cdot 0$ \\
\hline $\mathrm{NaCl}$ range for growth $(\%)$ & $0-2$ & $0-1 \cdot 25$ \\
\hline Temperature range for growth $\left({ }^{\circ} \mathrm{C}\right)$ & $6-40$ & $5-39$ \\
\hline \multicolumn{3}{|l|}{ Hydrolysis of: } \\
\hline Gelatin & $\mathrm{W}$ & - \\
\hline Starch & - & + \\
\hline Tween 20 & - & + \\
\hline Tween 80 & - & + \\
\hline \multicolumn{3}{|l|}{ Acid from: } \\
\hline D-Cellobiose & - & + \\
\hline D-Fructose & - & + \\
\hline D-Galactose & - & + \\
\hline D-Sucrose & - & + \\
\hline \multicolumn{3}{|l|}{ Utilization of: } \\
\hline L-Arabinose & + & - \\
\hline D-Glucose & + & - \\
\hline D-Lactose & + & - \\
\hline \multicolumn{3}{|l|}{ Susceptibility to: } \\
\hline Erythromycin & - & + \\
\hline Kanamycin & - & + \\
\hline Lincomycin & - & + \\
\hline Oleandomycin & - & + \\
\hline Streptomycin & - & + \\
\hline Tetracycline & - & + \\
\hline
\end{tabular}

The main isoprenoid quinone is MK-7. The genus is a member of the phylum 'Bacteroidetes'. The type species is Larkinella insperata.

\section{Description of Larkinella insperata sp. nov.}

Larkinella insperata (in.spe.ra'ta. L. fem. adj. insperata unexpected, referring to the unexpected source from which the bacterium was isolated). 
Table 3. Phenotypic properties that distinguish the genus Larkinella from related taxa

Data from Larkin \& Borrall (1984), Chelius \& Triplett (2000), Chelius et al. (2002), Reddy \& Garcia-Pichel (2005) and this study. W, Weakly positive.

\begin{tabular}{|c|c|c|c|c|}
\hline Characteristic & Larkinella & Spirosoma & Dyadobacter & Runella \\
\hline Habitat & Water & Freshwater, soil & Plants, soil & Freshwater, plants \\
\hline Colony colour & Pale pink & Yellow & Yellow & Salmon \\
\hline Cell morphology & $\begin{array}{l}\text { Ring-like and } \\
\text { horseshoe-shaped } \\
\text { cells }\end{array}$ & $\begin{array}{l}\text { Ring-like and } \\
\text { horseshoe-shaped } \\
\text { cells, filaments, } \\
\text { coils and helices } \\
\text { may be present }\end{array}$ & $\begin{array}{l}\text { Straight to curved } \\
\text { cells, filaments }\end{array}$ & $\begin{array}{l}\text { Slightly curved, often } \\
\text { horseshoe-shaped cells, } \\
\text { filaments, rarely coils } \\
\text { of two to three turns, } \\
\text { or straight to slightly } \\
\text { bent rods }\end{array}$ \\
\hline Gliding motility & + & + & - & + \\
\hline Flexirubin reaction & - & - & + & - \\
\hline $\begin{array}{l}\text { Highest } \mathrm{NaCl} \text { concentration tolerated } \\
\text { for growth }(\%)\end{array}$ & 2 & $1 \cdot 25$ & $1 \cdot 0-1 \cdot 5$ & $0 \cdot 75-1$ \\
\hline Growth on peptone water & - & - & + & + \\
\hline Maximum growth temperature $\left({ }^{\circ} \mathrm{C}\right)$ & 40 & 39 & $30-37$ & $37-42$ \\
\hline \multicolumn{5}{|l|}{ Hydrolysis of: } \\
\hline Gelatin & + & - & - & - \\
\hline Starch & - & + & - & $\mathrm{W}$ \\
\hline DNA G $+\mathrm{C}$ content $(\mathrm{mol} \%)$ & 53 & $51-53$ & 48 & 49 \\
\hline
\end{tabular}

Main characteristics are the same as those given for the genus. In addition, cells have an outer diameter of $1 \cdot 5-3 \cdot 0 \mu \mathrm{m}$ and width of $0.5-0.9 \mu \mathrm{m}$. Colonies are $1-2 \mathrm{~mm}$ in diameter, circular and shiny with entire edges. Growth is observed at $10-40{ }^{\circ} \mathrm{C}$ and with $0-2 \% \mathrm{NaCl}$. $\beta$-Galactosidase-positive. Decomposes gelatin and Tween 40 . Does not degrade agar, casein, starch, DNA, Tweens 20 or 80, urea, cellulose (CMcellulose or filter paper) or chitin. Does not produce acid from adonitol, L-arabinose, D-cellobiose, dulcitol, D-fructose, L-fucose, D-galactose, $\mathrm{N}$-acetylglucosamine, D-glucose, glycerol, inositol, D-lactose, D-maltose, mannitol, D-melibiose, L-raffinose, L-rhamnose, sorbitol, L-sorbose, D-sucrose, Dxylose or L-xylose. Utilizes L-arabinose, D-glucose, D-lactose, D-mannose and D-sucrose as sole carbon sources for growth, but not citrate, inositol, malonate, mannitol or sorbitol. Flexirubin-type pigments are absent. Does not reduce nitrate. No production of $\mathrm{H}_{2} \mathrm{~S}$, indole or acetoin (VogesProskauer reaction). Susceptible to ampicillin, carbenicillin and doxycycline; resistant to benzylpenicillin, chloramphenicol, erythromycin, gentamicin, kanamycin, lincomycin, neomycin, oleandomycin, polymyxin $\mathrm{B}$, streptomycin and tetracycline. Major fatty acid components $(>1 \cdot 0 \%)$ include $14: 0,15: 0$ iso, $15: 0$ anteiso, $15: 0$ iso $3-\mathrm{OH}, 16: 0$, $16: 1 \omega 5 c, 16: 03-\mathrm{OH}, 16: 0$ iso $3-\mathrm{OH}, 17: 0$ iso $3-\mathrm{OH}$ and summed feature 3 (comprising $15: 0$ iso 2-OH, $16: 1 \omega 7 c$ and/or $16: 1 \omega 7 t)$. The $\mathrm{G}+\mathrm{C}$ content of the DNA is $53 \cdot 0 \mathrm{~mol} \%$.

The type strain is LMG $22510^{\mathrm{T}}\left(=\mathrm{NCIMB} 14103^{\mathrm{T}}\right.$ ), isolated from water produced by a steam generator in a pharmaceutical company in Belgium.

\section{Acknowledgements}

This research was supported by the Belgian Federal Public Planning Service - Science Policy; O. I. N. was supported by grants of the Federal Agency for Sciences and Innovations of the Ministry for Education and Sciences of the Russian Federation no. 2-2.16, the Russian Foundation for Basic Research no. 05-04-48211 and the Program of Fundamental Investigations of the Presidium of the Russian Academy of Sciences 'Molecular and Cell Biology'.

\section{References}

Akagawa-Matsushita, M., Itoh, T., Katayama, Y., Kuraishi, H. \& Yamasato, K. (1992). Isoprenoid quinone composition of some marine Alteromonas, Marinomonas, Deleya, Pseudomonas and Shewanella species. J Gen Microbiol 138, 2275-2281.

Chelius, M. K. \& Triplett, E. W. (2000). Dyadobacter fermentans gen. nov., sp. nov., a novel Gram-negative bacterium isolated from surface-sterilized Zea mays stems. Int J Syst Evol Microbiol 50, 751-758.

Chelius, M. K., Henn, J. A. \& Triplett, E. W. (2002). Runella zeae sp. nov., a novel Gram-negative bacterium from the stems of surface-sterilized Zea mays. Int J Syst Evol Microbiol 52, 2061-2063.

Ivanova, E. P., Zhukova, N. V., Svetashev, V. I., Gorshkova, N. M., Kurilenko, V. V., Frolova, G. M. \& Mikhailov, V. V. (2000). Evaluation of phospholipid and fatty acid compositions as chemotaxonomic markers of Alteromonas-like proteobacteria. Curr Microbiol 41, 341-345.

Larkin, J. M. \& Borrall, R. (1984). Family I. Spirosomaceae Larkin and Borrall 1978, 595 ${ }^{\mathrm{AL}}$. In Bergey's Manual of Systematic Bacteriology, vol. 1, pp. 125-126. Edited by N. R. Krieg \& J. G. Holt. Baltimore: Williams \& Wilkins. 
Leisner, J. J., Vancanneyt, M., Lefebvre, K., Vandemeulebroecke, K., Hoste, B., Euras Vilalta, N., Rusul, G. \& Swings, J. (2002). Lactobacillus durianis sp. nov., isolated from an acid-fermented condiment (tempoyak) in Malaysia. Int J Syst Evol Microbiol 52, 927-931.

Mesbah, M., Premachandran, U. \& Whitman, W. B. (1989). Precise measurement of the $\mathrm{G}+\mathrm{C}$ content of deoxyribonucleic acid by high-performance liquid chromatography. Int J Syst Bacteriol 39, 159-167.

Nedashkovskaya, O. I., Suzuki, M., Vysotskii, M. V. \& Mikhailov, V. V. (2003). Reichenbachia agariperforans gen. nov., sp. nov., a novel marine bacterium in the phylum Cytophaga-FlavobacteriumBacteroides. Int J Syst Evol Microbiol 53, 81-85.

Nedashkovskaya, O. I., Kim, S. B., Han, S. K., Rhee, M. S., Lysenko, A. M., Falsen, E., Frolova, G. M., Mikhailov, V. V. \& Bae, K. S. (2004). Ulvibacter litoralis gen. nov., sp. nov., a novel member of the family Flavobacteriaceae isolated from the green alga Ulva fenestrata. Int J Syst Evol Microbiol 54, 119-123.

Niemann, S., Puhler, A., Tichy, H.-V., Simon, R. \& Selbitschka, W. (1997). Evaluation of the resolving power of three different DNA fingerprinting methods to discriminate among isolates of a natural Rhizobium meliloti population. J Appl Microbiol 82, 477-484.

Nikitin, D. I., Strömpl, C., Oranskaya, M. S. \& Abraham, W.-R. (2004). Phylogeny of the ring-forming bacterium Arcicella aquatica gen. nov., sp. nov. (ex Nikitin et al. 1994), from a freshwater neuston biofilm. Int J Syst Evol Microbiol 54, 681-684.

Pitcher, D. G., Saunders, N. A. \& Owen, R. J. (1989). Rapid extraction of bacterial genomic DNA with guanidium thiocyanate. Lett Appl Microbiol 8, 151-156.

Reddy, G. S. N. \& Garcia-Pichel, F. (2005). Dyadobacter crusticola sp. nov., from biological soil crusts in the Colorado Plateau, USA, and an emended description of the genus Dyadobacter Chelius and Triplett 2000. Int J Syst Evol Microbiol 55, 1295-1299.

Vancanneyt, M., Mengaud, J., Cleenwerck, l., Hoste, B., Dawyndt, P., Degivry, M. C., Ringuet, D., Janssens, D. \& Swings, J. (2004). Reclassification of Lactobacillus kefirgranum Takizawa et al. 1994 as Lactobacillus kefiranofaciens subsp. kefirgranum subsp. nov. and emended description of L. kefiranofaciens Fujisawa et al. 1988. Int J Syst Evol Microbiol 54, 551-556. 